\title{
Efektivitas Promosi Di Media Sosial Pada Keputusan Pembelian Pelanggan Di Gallery DEWDEW Collection Berdasarkan Model AIDA
}

\author{
Arista Dini Nurhidayanti ${ }^{1}$, Ambar Tri Hapsari ${ }^{2}$, Khoirul Umam ${ }^{3}$ \\ Universitas Indraprasta PGRI ${ }^{1,2,3}$
}

\begin{abstract}
The purpose of this study is to answer the question of whether the promotion carried out by the Dewdew Collection Gallery is effective in making consumers decide to buy their products. This type of research is quantitative descriptive using cross sectional data that occurred in July 2019. Based on the results of research from 35 respondents samples of consumers with affordable populations, using the Guttman scale and KR 20, obtained information that the Attention dimension of 0.82 which means, promotion can attract attention. Interest dimension of 0.95 which means that promotion can arouse consumer interest to buy. The dimension of the Desire is 0.64. Even though it is not too big, it can be categorized as being able to bring up the desire of consumers to buy. And the Action dimension of 0.79 which means that the promotion has been able to move the consumer's decision to buy. The final result of an average of 4 dimensions of AIDA of 0.8, which means that the promotion carried out by the Dewdew Collection Gallery through online social media as a whole is effective.
\end{abstract}

Keywords: AIDA, Purchasing Decisions, Social Media, Promotions

\section{Pendahuluan}

Media sosial adalah metode komunikasi digital di mana pengguna berinteraksi satu sama lain, berbagi dan mengkonsumsi konten dengan cara yang diatur dengan platform tertentu. Kebutuhan berkomunikasi melalui media sosial sebagai moda komunikasi saat ini sangat diperlukan untuk sebagian besar kegiatan bisnis di dunia saat ini karena kemampuannya untuk mengirimkan konten secara langsung kepada konsumen, basis pengguna yang besar, biaya yang relatif rendah untuk memulai dan pemeliharaan, dan kemampuannya bagi bisnis untuk menerima ummpan balik tanpa halangan secara langsung dari konsumen (Ranginwala \& Towbin, 2017). Dalam kegiatan bisnis saat ini, kebutuhan konsumen terhadap media sosial melalui internet sangat besar untuk mendapatkan informasi produk 
sebelum melakukan pembelian melalui online. Kondisi ini memicu pelaku usaha mulai memanfaatkan media online sebagai sarana komunikasi dalam menyampaikan pesan komersialnya, memperkenalkan atau mempromosikan produknya. Kotler dan Keller (2016: 637) menjelaskan, "Saluran terbaru dan paling cepat berkembang untuk berkomunikasi dan menjual langsung ke pelanggan adalah digital”. Komponen penting dalam pemasaran digital adalah media sosial. Media sosial merupakan suatu alat untuk meningkatkan penjualan serta mengukur jangkauan dari segala promosi penjualan sebagaimana yang dilakukan Gallery Dewdew Collection yang bergerak dibidang jasa agensi model, make up artist (MUA), penyewaan gaun, make up wisuda, dan wedding package yang didirikan oleh Dewi Kesiha Aprilia tahun 2014 dan beralamat di Jl. Swatantra I Kav. 5 No. 99 RT. 009 RW. 005, Kel. Jatirasa Kec. Jatiasih Kota Bekasi 17424.

Dalam memasarkan produknya Gallery Dewdew Collection menggunakan media sosial sebagai alat komunikasi pemasarannya. Perusahaan menggunakan media sosial karena merasa bahwa masyarakat saat ini terus menerus ingin berubah dan berkembang untuk memenuhi segala tuntutan era global. Walaupun tingkat kepercayaan masyarakat dalam menggunakan media sosial dalam berbelanja online tidak selalu stabil terutama di bidang jasa make up, tak menyurutkan niat Dewi Keisha Aprilia selaku ownerGallery Dewdew Collectionuntuk melakukan promosi di akun media sosialnya yaitu facebook dan instagram. Berikut ini adalah data hasil penjualan jasa Class Modelling pada event Photo Contest dan event Fashion Show untuk 4 tahun terakhir, yaitu sebagai berikut:

Berdasarkan data yang diperoleh, tahun 2015 Gallery Dewdew Collection hanya menggunakan media sosial facebook sebagai media promosi online untuk memasarkan produknya dan memperoleh pendapatan Rp 6.000.000,- per event photo contestdengan modal Rp 4.000.000,-. Kemudian di tahun 2016 Dewi menggunakan promosi langsung melalui brosur dan media sosial facebook untuk memasarkan produknya. Modal yang dikeluarkan cukup besar yaitu Rp 12.000.000,- dan memperoleh pendapatan sebesar Rp 22.000.000,-. Pada tahun 2017-2018 hanya menggunakan media sosial Instagram saja. Di tahun 2017 meningkat sebesar 2 juta rupiah menjadi Rp 24.000.000,- dan di tahun terakhir 
sebesar Rp 28.500.000,- dengan modal masing-masing $\mathrm{Rp}$ 4.000.000,-Berdasarkan pemaparan tersebut terlihat adanya kenaikan pendapatan dari setiap tahunnya dari berbagai jenis promosi yang digunakan.

Berdasarkan penelitian Hening Ary Putra (2014), menjelaskan bahwa iklan dan promosi online pada media sosial dapat mempengaruhi perilaku konsumen dalam melakukan pembelian. Jika konsumen tertarik terhadap promosi yang ditampilkan pada media sosial, maka konsumen dapat melakukan pembelian terhadap produk dalam promosi tersebut.

Untuk memahami proses terjadinya respon dari konsumen, pemasar harus mengembangkan pesan yang efektif dalam melakukan promosi online. Idealnya pesan yang efektif tersebut harus menarik perhatian, mengembangkan ketertarikan (interest), membangkitkan keinginan (desire), dan menggerakkan tindakan (action). Promosi yang berhasil akan menimbulkan tindakan dari konsumen yaitu berupa pembelian, sebelum terjadinya pembelian terdapat tahap-tahap yang disebut Hierarchy-of-effect adalah tingkatan pengaruh iklan terhadap konsumen. Teori Hierarchy-of-effect yang paling terkenal adalah AIDA (attention, interest, desire, action). Berdasarkan model AIDA ini diasumsikan bahwa promosi melalui tahap ini merupakan faktor penentu keberhasilan suatu promosi online yang akan meningkatkan perhatian dan minat.

\section{Tinjauan Pustaka}

\section{Komunikasi Pemasaran}

Konsep dasar komunikasi pemasaran adalah pertukaran.Pertukaran yang dimaksud adalah terjadi pertukaran nilai antara perusahaan dan konsumen.Baik itu pertukaran dalam bentuk ekonomis maupun pertukaran dalam bentuk nilai hubungan.Agar sebuah pertukaran nilai dapat terjadi dibutuhkan suatu penggabungan komunikasi yang efektif dan strategi pemasaran yang baik, dimana penetapan pelaksanaan komunikasi yang efektif tersebut membantu pelaksanaan pemasaran.

Komunikasi pemasaran adalah sarana yang digunakan perusahaan untuk memberi informasi, membujuk, dan mengingatkan konsumen secara langsung atau 
tidak langsung tentang produk dan merek yang mereka jual (Kotler dan Keller, 2016: 580).

Ferrel dan Hartline (2011: 291) menjelaskan bahwa, kegiatan promosi diperlukan untuk mengkomunikasikan fitur dan manfaat suatu produk ke target pasar yang dituju perusahaan.Komunikasi pemasaran mencakup penyampaian dan berbagi makna antara pembeli dan penjual, baik sebagai individu dan perusahaan, atau antara individu dan perusahaan.

American Marketing Association (AMA) mendefinisikan Komunikasi Pemasaran Terpadu atau Integrated Marketing Communications (IMC) sebagai proses perencanaan yang dirancang untuk memastikan bahwa semua kontak merek yang diterima oleh pelanggan atau prospek untuk suatu produk, jasa, atau organisasi adalah relevan dengan mereka dan konsisten dari waktu ke waktu (Kotler dan Keller, 2016: 599). Komunikasi pemasaran terpadu mengacu pada penggunaan promosi yang strategis dan terkoordinasi untuk membuat satu pesan yang konsisten di berbagai saluran untuk memastikan dampak persuasif maksimun pada pelanggan saat ini dan pelanggan potensial.

Dari berbagai definisi komunikasi pemasaran di atas, dapat disimpulkan bahwa komunikasi pemasaran memegang peranan yang sangat penting bagi perusahaan atau pelaku usaha. Sebagus apapun rancangan strategi pemasaran yang dirancang, tanpa komunikasi yang efektif dan efisien, konsumen maupun masyarakat lainnya tidak akan mengetahui keberadaan produk tersebut di pasar.

\section{Langkah-langkah Pengembangan Komunikasi Pemasaran yang Efektif}

Ada delapan langkah untuk mengembangkan program komunikasi pemasaran yang efektif menurut Kotler dan Keller (2016:586), yaitu:

\section{1) Mengidentifikasi Sasaran Penonton (Identify Target Audience)}

Proses tersebut harus dimulai dengan target audiens yang jelas dalam pikiran seperti: calon pembeli produk, perusahaan, pengguna saat ini, penentu atau influencer, serta individu, kelompok tertentu atau masyarakat umum. Target audience adalah pengaruh penting pada keputusan komunikator tentang apa yang harus dikatakan, bagaimana, kapan, dimana, dan kepada siapa. 


\section{2) Menentukan Tujuan Komunikasi Pemasaran (Determine Objectives)}

Ada 4 tujuan komunikasi pemasaran.pertama,, Menetapkan kebutuhan akan kategori (category need). Menetapkan kategori produk atau jasa yang diperlukan untuk menghilangkan atau memuaskan perbedaan yang dirasakan antara keadaan motivasi saat ini dan keadaan motivasi yang diinginkan. Kedua, membangun kesadaran merek (brand awareness). Yaitu menumbuhkan kemampuan konsumen untuk mengenali atau mengingat kembali merek secara cukup rinci untuk melakukan pembelian. Ketiga, Membangun perilaku akan merek (brand attitude). Yaitu membantu konsumen mengevaluasi kemampuan merek untuk memenuhi kebutuhan yang relevan saaat ini.Kebutuhan merek yang relevan dapat berorientasi negatif (solusi masalah, penghindaran masalah, kepuasan tidak lengkap, deplesi normal) atau berorientasi postif (kepuasan indera, stimulasi intelektual, atau persetujuan sosial). Keempat, Intensitas pembelian terhadap merek (brand purchase intention). Yaitu menggerakkan konsumen untuk memutuskan dalam membeli merek atau melakukan tindakan terkait pembelian.

\section{3) Mendesain Pesan Komunikasi (Design Communications)}

Dalam mendesain komunikasi untuk mencapai respon yang diinginkan memerlukan menjawab 3 (tiga) pertanyaan berikut: apa yang harus dikatakan (message strategy), bagaimana mengatakan (creative strategy), dan siapa yang harus mengatakan (message source).

4) Memilih Saluran Promosi. antara lain: a) Saluran Komunikasi Pribadi, yaitu dua responden atau lebih yang berkomunikasi tatap muka atau melalui telepon dan e-mail. Termasuk pemasaran langsung, personal selling, dan word of mouth. b) Saluran Advokat, terdiri dari tenaga penjualan perusahaan yang menghubungi pembeli di pasar sasaran. c) Saluran Pakar, terdiri dari pakar independen yang membuat pernyataan kepada pembeli. d) Saluran Sosial, terdiri dari tetangga, teman, anggota keluarga, dan rekan yang berbicara dengan pembeli.

\section{5) Menyusun Anggaran Promosi}

Berikut ini empat metode bagaimana perusahaan menetapkan anggaran komunikasi pemasaran mereka, yaitu: a) Metode kemampuan bayar (Affordable 
Method); b) Metode berdasarkan persentasi penjualan (Percentage-of-sales Method); c) Metode competitive-parity; d) Metode berdasarkan tujuan dan tugas (Objectives-and-task Metohod)

\section{6) Menentukan Bauran Promosi Terintegrasi}

Dalam mengatur bauran komunikasi pemasaran, perusahaan harus mempertimbangkan beberapa faktor, diantaranya adalah Jenis produk pasar; tahapan kesiapan konsumen untuk melakukan pembelian; dan tahap dalam siklus hidup produk.

\section{7) Mengimplementasikan Program IMC (Integrated Marketing Communication)}

Komunikasi pemasaran terpadu dapat menghasilkan konsistensi pesan yang lebih kuat dan membantu membangun ekuitas merek serta menciptakan dampak penjualan yang lebih besar (Kotler dan Keller, 2016: 601). Manajemen harus memikirkan setiap cara agar pelanggan melakukan kontak dengan perusahaan, bagaimana perusahaan mengomunikasikan posisinya, kepentingan yang relatif dari setiap kendaraan, dan masalah waktu.

\section{8) Mengevaluasi Hasil Program IMC (Integrated Marketing Communication)}

Dalam menilai dampak kolektif dari program IMC, tujuan utama pemasar adalah menciptakan program komunikasi yang paling efektif dan efisien. Kriteria “Six Cs" menurut Kotler dan Keller (2016: 601) berikut dapat membantu menentukan apakah komunikasi benar-benar terintegrasi, yaitu sebagai berikut:

a. Coverage (Cakupan)

Cakupan adalah proporsi audiens yang dicapai oleh setiap opsi komunikasi yang digunakan serta jumlah tumpang tindih di antara opsi-opsi tersebut. Dengan kata lain, sejauh mana pilihan komunikasi yang berbeda mencapai target pasar yang ditentukan dan apakah konsumen yang sama atau berbeda yang membentuk pasar tersebut.

b. Contribution (Kontribusi)

Kontribusi adalah kemampuan inheren dari komunikasi pemasaran untuk menciptakan respon dan efek komunikasi yang diinginkan dari 
konsumen tanpa adanya paparan terhadap pilihan komunikasi lainnya. Seberapa besar komunikasi mempengaruhi konsumen dan membangun kesadaran, meningkatkan citra, memperoleh respon, dan meningkatkan penjualan.

c. Commonality (Kesamaan)

Commonality adalah sejauh mana pilihan komunikasi yang berbeda memiliki makna yang sama. Konsistensi dan kekompakkan citra merek adalah penting karena menentukan seberapa mudah respon yang ada dapat ditarik kembali dan seberapa mudah respon tambahan dapat dikaitkan dengan merek dalam memori.

d. Complementarity (Komplementaritas)

Pilihan komunikasi seringkali lebih efektif apabila digunakan secara bersamaan. Komplementaritas berkaitan dengan sejauh mana berbagai asosiasi dan hubungan ditekankan di seluruh pilihan komunikasi. Untuk membentuk penentuan posisi yang efektif, merek biasanya perlu membentuk beberapa asosiasi merek. Pilihan komunikasi pemasaran yang berbeda mungkin lebih cocok untuk membentuk asosiasi merek tertentu. Misalnya, sponsorship dapat meningkatkan persepsi kepercayaan dan kredibilitas suatu merek, tetapi televisi dan iklan cetak mungkin diperlukan untuk mengkomunikasikan keunggulan kinerjanya.

e. Conformability (Kesesuaian)

Kesesuaian mengacu pada sejauh mana pilihan komunikasi pemasaran berfungsi untuk suatu kelompok konsumen. Kemampuan untuk bekerja di dua tingkat yaitu berkomunikasi secara efektif dengan konsumen yang pernah dan yang belum melihat komunikasi lain sangat penting.

\section{f. $\quad \operatorname{Cost}($ Biaya)}

Pemasar harus mengevaluasi komunikasi pemasaran pada semua kriteria terhadap kemampuan biaya yang dimiliki untuk sampai pada program komunikasi yang paling efektif dan paling efisien. 


\section{Pemasaran Digital}

Dengan teknologi yang semakin berkembang, perusahaan dapat memanfaatkan situasi tersebut untuk menjangkau konsumen dengan mudah. Kotler dan Armstrong (2018:515) menjelaskan, meluasnya penggunaan internet dan teknologi digital memiliki dampak dramatis pada pembeli dan pemasar yang melayani mereka. Pemasaran digital terlibat langsung dengan individu dan komunitas pelanggan yang ditargetkan dengan hati-hati untuk memperoleh respon langsung dan membangun hubungan pelanggan yang langgeng. Berikut ini bentukbentuk dari pemasaran digital menurut Kotler dan Armstrong (2018), yaitu:

\section{Pemasaran Online}

Pemasaran online adalah pemasaran melalui internet menggunakan perusahaan situs web, iklan dan promosi online, email, video online, dan blog(Kotler dan Armstrong, 2018: 516).

Jadi, dapat dikatakan pemasaran online adalah kegiatan menjual produk berupa barang atau jasa melalui internet. Terdapat berbagai cara untuk melakukan pemasaran secara online, yaitu:

1) Situs Web dan Komunitas Web Bermerek (Websites and Branded Web Communities)

Situs web pemasaran, yang dirancang untuk melibatkan pelanggan dan memindahkan mereka lebih dekat ke pembelian langsung atau hasil pemasaran lainnya. Sebaliknya, situs web komunitas merek melakukan lebih dari sekadar menjual produk. Tujuan utama mereka adalah untuk menyajikan konten merek yang melibatkan konsumen dan menciptakan komunitas merek konsumen. Situs-situs tersebut biasanya menawarkan beragam informasi merek, video, blog, kegiatan, dan fitur lain yang membangun hubungan pelanggan yang lebih dekat dan menghasilkan keterlibatan dengan dan antara merek dan pelanggannya.

2) Iklan Online \& Promosi Online (Online Advertising \& Online Promotion)

\section{a) Iklan Online}

Perusahaan mengalihkan lebih banyak uang pemasaran mereka ke iklan online untuk membangun penjualan merek atau menarik 
pengunjung ke internet, ponsel, dan situs media sosial mereka. Iklan online telah menjadi media promosi utama. Bentuk utama dari iklan online adalah iklan bergambar dan iklan yang terkait dengan pencarian.

\section{b) Promosi Online}

Promosi online adalah proses kegiatan yang dilakukan oleh pihak perusahaan dalam menawarkan produk barang atau jasa yang dikenalkan atau diiklankan melalui media online (internet), sehingga tidak terjadi tatap muka langsung antara pembeli dan penjual (Jamaludin, 2015).

Dalam ilmu marketing, promosi merupakan salah satu komponen dalam bauran pemasaran atau marketing mix(product, price, place, dan promotion). Terkait dengan strategi dan teknik dalam pemasaran online, kegiatan promosi juga memegang peranan penting, terutama dalam rangka menghasilkan traffic(kunjungan). Maka munculah yang dinamakan dengan promosi online. Secara sederhana, promosi onlinedapat diartikansebagai kegiatan berpromosi yang dilakukan menggunakan media internet.

Wikan Pribadi (2010:9) mengatakan bahwa promosi online memiliki beberapa aspek, yaitu: 1) Menarik perhatian. Salah satu cara supaya individu tertarik dengan promosi yang ditawarkan pemasar secara online adalah dengan membuat judul atau subjudul yang menarik. Hal ini dikarenakan judul atau subjudul merupakan pintu utama dalam membuka peluang untuk menjual produk yang ditawarkan. 2) Menarik minat. Langkah selanjutnya dalam promosi online adalah dengan menarik minat individu. Caranya yaitu dengan menginformasikan bahwa produk yang dijual merupakan solusi yang tepat untuk mengatasi masalah yang dihadapi oleh idividu yang bersangkutan. Selain itu, dapat juga menyertakan testimonial dari para konsumen yang telah melakukan pembelian produk yang dijual. 3) Menarik hasrat. Langkah berikutnya adalah mengubah minat menjadi hasrat membeli dengan cara menjelaskan secara detail tentang fitur, manfaat, kelebihan dan keuntungan dari produk yang dijual. 4) Menarik 
tindakan. Setelah individu memiliki hasrat, langkah selanjutnya adalah membuat tahapan pemesanan produk semudah mungkin. 5) Memberikan penutup yang baik. Pada bagian akhir, diperlukan adanya pemberian jaminan, garansi, atau bonus produk yang dijual, atau dapat juga menyantumkan kontak yang dapat dihubungi oleh calon pembeli.

\section{3) E-mail Marketing}

Pemasaran email merupakan alat pemasaran digital yang penting dan terus berkembang. Bila digunakan dengan benar, e-mail dapat menjadi media pemasaran langsung terbaik. E-mailsaat ini sama sekali bukan hanya sekadar pesan singkat atau teks saja. Sebaliknya, e-mail penuh warna, mengundang, dan interaktif. E-mail memungkinkan pemasar mengirim pesan yang sangat bertarget, sangat pribadi, dan membangun hubungan. Tetapi ada sisi gelap dari meningkatnya penggunaan pemasaran $e$-mail. Ledakan spam pesan $e$ mail komersial yang tidak diinginkan telah menimbulkan kekesalan dan frustrasi konsumen.

\section{4) Online Videos}

Bentuk lain dari pemasaran online adalah memposting konten video digital di situs web merek atau di situs media sosial seperti Youtube, Facebook, Vine, dan lainnya. Pemasar berharap bahwa beberapa video mereka akan viral (trending topik, atau menjadi perbincangan banyak responden dalam hal yang positif). Pemasaran viral (viral marekting) adalah versi digital dari pemasaran dari mulut ke mulut, melibatkan pembuatan video, iklan, dan konten pemasaran lainnya yang sangat menular sehingga pelanggan akan mencari atau membagikannya kepada teman-teman mereka. Karena pelanggan menemukan dan meneruskan konten, pemasaran viral bisa sangat murah. Ketika konten berasal dari seresponden teman, penerima kemungkinan besar akan melihat atau membacanya.

\section{5) Blogs and Other Online Forums}

Brands juga melakukan pemasaran online melalui berbagai forum digital yang menarik bagi kelompok minat khusus dan komunitas merek 
tertentu. Blog (atau logweb) adalah forum online tempat responden dan perusahaan membagikan pemikiran mereka dan konten lainnya, biasanya terkait dengan topik yang didefinisikan secara sempit.

Sebagai alat pemasaran, blog menawarkan beberapa keuntungan. Mereka dapat menawarkan cara yang segar, orisinil, pribadi, dan murah untuk memasuki percakapan konsumen online dan media sosial. Blog sebagian besar merupakan media yang dikendalikan konsumen. Apakah mereka berpartisipasi aktif dalam blog atau tidak, perusahaan harus memantau dan mendengarkan mereka. Pemasar dapat menggunakan wawasan dari percakapan online konsumen untuk meningkatkan program pemasaran mereka.

\section{6) Pemasaran Media Sosial (Social Media Marketing)}

Sosial media adalah jaringan sosial online independen dan komersial tempat responden berkumpul untuk bersosialisasi dan berbagi pesan, pendapat, gambar, video, dan konten lainnya (Kotler dan Armstrong, 2018:521). Terdapat beberapa keuntungan dalam menggunakan sosial media sebagai pemasaran yaitu:

a. Media sosial ditargetkan dan bersifat pribadi yang memungkinkan pemasar membuat dan berbagi konten merek yang disesuaikan dengan individu konsumen dan komunitas pelanggan.

b. Media sosial juga segera dan tepat waktu. Mereka dapat digunakan untuk menjangkau pelanggan kapan saja, di mana saja dengan konten pemasaran yang tepat waktu dan relevan mengenai kejadian dan aktifitas merek.

c. Media sosial bisa sangat hemat biaya. Meskipun membuat dan mengelola konten media sosial bisa mahal, banyak media sosial gratis atau murah untuk digunakan. Biaya rendah dari media sosial membuat mereka mudah dijangkau bahkan oleh usaha kecil dan merek yang tidak mampu membayar biaya tinggi dari kampanye pemasaran beranggaran besar. 
d. Keuntungan terbesar dari media sosial adalah keterlibatan dan kemampuan berbagi sosial mereka. Media sosial sangat cocok untuk menciptakan keterlibatan pelanggan dan komunitas, untuk melibatkan pelanggan dengan merek dan satu sama lain. Media sosial dapat melibatkan pelanggan dalam membentuk dan berbagi konten, pengalaman, informasi, dan gagasan merek.

Pemasaran melalui media sosial bukan hanya memberikan keuntungan tetapi tantangan yang harus dihadapi oleh sebuah perusahaan. Berikut beberapa tantangan dalam pemasaran media sosial:

a. Banyak perusahaan masih bereksperimen dengan cara menggunakannya secara efektif dan hasilnya sulit diukur.

b. Jejaring sosial sebagian besar dikendalikan oleh pengguna. Para pemasar tidak bisa begitu saja memasuki interaksi digital konsumen, mereka perlu mendapatkan hak untuk berada di sana. Pemasar harus menjadi bagian yang berharga dari pengalaman online dengan mengembangkan aliran konten yang menarik.

Clow dan Baack (2018:286) mengungkapkan beberapa strategi media sosial utama yaitu:

\section{Content seeding (menyebar konten)}

Menyebar konten termasuk melibatkan penawaran insentif kepada konsumen untuk berbagi konten tentang suatu merek. Penawaran konten dapat berupa informasi, keunikan, sesuatu yang baru, atau apa pun yang melibatkan konsumen dan memotivasi mereka untuk berbagi dengan responden lain.

\section{Real-timemarketing (pemasaran secara langsung)}

Pemasaran waktu nyata adalah pembuatan dan pelaksanaan dalam menaggapi pesan pemasaran instan dan dilakukan bersama dengan acara/kejadian pada waktu dan tempat tertentu secara langsung. Pemasaran real-time yang efektif tidak terjadi dengan cepat tanpa berpikir. Pendekatan ini membutuhkan perencanaan strategis dimuka sebelum acara langsung.

\section{Video Marketing (Pemasaran Video),}


Pemasaran profesionalmenyadari bahwa Youtube dan platform berbagi video lainnya menghadirkan peluang dan tantangan unik untuk pemasaran media sosial. Berbagai cara mereka lakukan untuk membuat pemasaran melaui video, seperti:

a) Membuat iklan video di Youtube atau platform berbagi video lainnya yang menjelaskan atau mendeskripsikan produk, merek, kegunaan, cara menggunakan, manfaat dan kelebihan produk mereka.

b) Iklan yang disematkan dalam video, bukan hanya video produk mereka tetapi juga video individu-individu yang di upload di berbagai platform berbagai video. Iklan dapat berupa pra-putar (sebelum video dimulai), paruh-putar (di tengah konten video), atau pasca-putar (di akhir konten).

c) Membayar individu untuk mempromosikan merek telah menjadi strategi terbaru di arena video. Responden-responden ini, yang dikenal sebagai vloggers, membuat video, mempostingnya di situs video seperti Youtube atau Vine, dan berupaya menambah pengikut.

\section{Influencer Marketing}

Influencer adalah responden-responden yang punya followers atau audience yang cukup banyak di social media dan mereka punya pengaruh yang kuat terhadap followersmereka, seperti artis, selebgram, blogger,youtuber, dan lain sebagainya. Influencer yang paling efektif adalah individu yang memimpin percakapan dan membentuk opini.

Menyelaraskan pesan merek dengan motivasi influencer akan menjadi kunci keberhasilan. Influencer mencoba menumbuhkan jaringan pengikut. Kebanyakan responden tidak menentang influencer yang melempar merek tertentu selama itu merupakan pujian yang tulus terhadap merek tersebut.

\section{Interactive Blogs (Blog Interaktif)}

Blog interaktif memungkinkan pengunjung untuk mengirim komentar atau posting, menjadikannya komponen penting lain dari media sosial. Terdapat tiga jenis blog interaktif antara lain: 
a) Brand blog, blog yang dibuat oleh perusahaan atau pemegang merek. Blog yang dimiliki dan dioperasikan oleh bisnis sulit untuk meminta interaksi jujurdengan konsumen yang mungkin lebih mencurigakan. Juga, personil perusahaan yang mengoperasikan blog mungkin lebih sensitif terhadap konten negatif dan bagaimana pelanggan melihat organisasi.

b) Individuals sponsored by a brand, penulis blog yang disponsori oleh perusahaan atau pemegang merek. Individu-individu ini memiliki kebebasan untuk mengekspresikan pendapat pribadi, mereka cenderung harus tetap positif tentang merek untuk mempertahankan sponsornya. Pengunjung situs juga memiliki lebih banyak kebebasan untuk berkomentar.

c) Individual speaking about a brand, responden-responden yang menulis atau membicarakan tentang suatu merek tetapi tidak memiliki hubungan dengan perusahaan atau pemegang merek. Mereka senang membicarakan dan menikmati berinteraksi dengan responden lain tentang sebuah merek atau produk tertentu.

d) Consumer-Generated Reviews (Ulasan Konsumen), ulasan yang diberikan oleh konsumen membantu konsumen lain dalam membuat keputusan untuk pembelian akan suatu produk. Pemasar dengan seksama mempelajari ulasan yang dihasilkan oleh pelanggan, karena mereka memberikan evaluasi terhadap produk dan bagaimana item tersebut dibandingkan dengan pesaing. Informasi ini menjadi penting untuk mengembangkan rencana pemasaran, modifikasi produk, dan strategi layanan. Karena penggunaan ulasan yang dihasilkan oleh konsumen terus meningkat, tantangan pemasaran akan mengelola aspek dukungan dari mulut ke mulut dengan cara yang meningkatkan ekuitas merek dan meningkatkan penjualan.

\section{Viral Marketing}

Istilah viral berasal dari citra seseresponden yang "terinfeksi" dengan pesan pemasaran dan kemudian menyebarkannya ke teman-teman, seperti virus. 
Perbedaannya adalah bahwa individu secara sukarela mengirim pesan kepada responden lain. Pemasaran viral termasuk iklan, promosi hyperlink, buletin online, streaming video, dan permainan. Kunci suksesnya viral marketing yaitu:

a) Pesan viral harus fokus pada produk atau bisnis.

b) Tim pemasaran menentukan mengapa seseresponden ingin meneruskan pesan itu atau memberi tahu teman tentangnya.

c) Individu harus menerima insentif/bonus bila menyebarkan atau menyampaikan pesan pada produk yang dijual, seperti diskon atau pembelian buy one get one dan lain sebagainya yang bersifat unik.

d) Lacak dan analisis hasil viral marketing untuk menentukan apakah sudah efektif.

\section{Keputusan Pembelian}

Konsumen membuat banyak keputusan pembelian setiap hari, dan keputusan pembelian adalah titik fokus dari upaya pemasar. Keputusan pembelian aktual adalah bagian dari proses pembelian yang jauh lebih besar,mulai dari mengenali suatu kebutuhan hingga perilaku pasca pembelian (Kotler dan Armstrong, 2018:175). Keputusan pembelian merupakan tahap dari proses keputusan pembelian yaitu ketika konsumen benar-benar membeli produk. Dimanakonsumen mengenal masalahnya, mencari informasi mengenai produkatau merk tertentu dan mengevaluasi seberapa baik masing-masing alternatif tersebut dapat memecahkan masalahnya yang kemudian mengarah kepada keputusan pembelian.

Proses pembelian dimulai jauh sebelum pembelian aktual dan berlanjut lama setelah itu. Karena itu, pemasar harus fokus pada keseluruhan proses pembelian, bukan hanya keputusan pembelian.

\section{Tahap-tahap Proses Keputusan Pembelian}

Menurut Kotler dan Armstrong (2018:177) ada lima tahap proses pembelian konsumen, yaitu sebagai berikut:

1. Butuh Pengenalan/Pengakuan (Need Recognition)

Proses pembelian dimulai dengan pengenalan kebutuhan, maksudnya 
adalah pembeli mengenali masalah atau kebutuhannya. Kebutuhan dapat dipicu oleh rangsangan internal ketika salah satu kebutuhan normal seseresponden, misalnya lapar atau haus naik ke tingkat yang cukup tinggi untuk menjadi dorongan. Kebutuhan juga dapat dipicu oleh rangsangan eksternal. Pada tahap ini, pemasar harus meneliti konsumen untuk mengetahui jenis kebutuhan atau masalah apa yang muncul, apa yang menyebabkannya, dan bagaimana mereka mengarahkan konsumen ke produk tertentu ini.

\section{Pencarian Informasi (Information Search)}

Tahap pencarian informasi adalah tahap dimana konsumen termotivasi untuk cari informasi lebih lanjut. Jika dorongan konsumen kuat dan produk yang memuaskan sudah dekat, kemungkinan akan membelinya nanti. Jika tidak, konsumen dapat menyimpan kebutuhan dalam memori atau melakukan pencarian informasi terkait dengan kebutuhannya. Konsumen dapat memperoleh informasi dari beberapa sumber. Adapun beberapa jenis sumber yang dapat diperoleh, yaitu:

a) Sumber pribadi (keluarga, teman, tetangga, kenalan).

b) Sumber komersial (periklanan, tenaga penjualan, situs webdealer dan situs mobile, pengemasan, pajangan).

c) Sumber publik (media massa, organisasi penilaian konsumen, media sosial, pencarian online dan ulasan sejawat).

d) Sumber pengalaman (memeriksa dan menggunakan produk).

Semakin banyak informasi diperoleh, kesadaran dan pengetahuan konsumen tentang merek dan fitur yang tersedia meningkat.

3. Evaluasi Alternatif (Evaluation of Alternatives)

Setelah konsumen menggunakan informasi untuk sampai pada serangkaian pilihan merek akhir, selanjutnya adalah tahap evaluasi alternatif yaitu, bagaimana konsumen memproses informasi untuk memilih diantara merek-merek alternatif. Konsumen mengevaluasi pembelian alternatif tergantung pada diri konsumen tersebut dan situasi pembelian tertentu. Dalam beberapa kasus, konsumen menggunakan perhitungan yang cermat dan 
pemikiran logis. Di sisi lain, konsumen yang sama melakukan sedikit atau tidak sama sekali mengevaluasi. Sebaliknya, mereka membeli berdasarkan dorongan hati dan mengandalkan intuisi.

4. Keputusan Pembelian (Purchase Decision)

Menurut Kotler dan Armstrong (2018:177), "Keputusan pembelian adalah membeli merek yang paling disukai”. Maksudnya adalah konsumen membeli suatu produk berdasarkan merek yang paling mereka sukai.

Ada dua faktor yang akan muncul dalam pembelian suatu produk yaitu antara niat pembelian dan keputusan pembelian.Faktor pertama adalah sikap responden lain. Faktor kedua adalah faktor situasional yang tidak terduga. Konsumen dapat membentuk niat beli berdasarkan faktor-faktor seperti pendapatan yang diharapkan, harga yang diharapkan, dan manfaat produk yang diharapkan. Namun, kejadian tak terduga dapat mengubah niat pembelian.

5. Perilaku Pasca Pembelian (Postpurchase Behavior)

Tahap perilaku pasca pembelian adalah tahap dimana konsumen mengambil tindakan lebih lanjut setelah pembelian, berdasarkan kepuasan atau ketidakpuasan mereka yang terletak pada hubungan antara harapan konsumen dan persepsi kinerja produk. Jika produk kurang dari harapan, konsumen kecewa; jika memenuhi harapan, konsumen puas; dan jika melebihi harapan, konsumen senang. Semakin besar kesenjangan negatif antara harapan dan kinerja, semakin besar ketidakpuasan konsumen.

\section{AIDA Model}

Ferrel dan Hartline (2011:294), mengatakan bahwa tujuan dan sasaran dari setiap kampanye promosi berujung pada pembelian barang atau jasa oleh konsumen. AIDA (Attention, Interest, Desire, Action) merupakan tahapan dari tujuan adanya promosi atau iklan.

\section{a. Attention (Perhatian)}

Sebuah pesan dalam media promosi yang digunakan harus dapat menimbulkan perhatian pelanggan yang dijadikan target sasaran. Hal tersebut 
dapat dilakukan melalui tulisan dan gambar yang menonjol dan jelas, perkataan yang menarik atau mudah diingat, dan mempunyai karakteristik tersendiri. Ini merupakan langkah awal bagi pemasar dimana pesan tersebut akan dikenal, diketahui, dan diingat oleh konsumen. Proses tersebut bisa disebut sebagai proses awareness/kesadaran akan adanya produk yang disampaikan ke konsumen.

\section{b. Interest (Ketertarikan)}

Yang dimaksud tertarik ialah pesan yang disampaikan menimbulkan rasa ingin tahu, ingin mengamati, dan ingin mendengar serta melihat lebih seksama. Hal tersebut terjadi karena adanya minat yang menarik perhatian konsumen akan pesan yang ditunjukkan (Kotler dan Keller, 2009:178).

\section{c. Desire (Keinginan)}

Keinginan yang terjadi berkaitan dengan motif dan motivasi konsumen dalam membeli suatu produk. Motif pembelian dibedakan menjadi dua, yaitu motif rasional dan emosional. Motif rasional mempertimbangkan konsumen akan keuntungan dan kerugian yang didapatkan, sedangkan motif emosional terjadi akibat emosi akan pembelian produk (Kotler dan Keller, 2009:178).

\section{d. Action (Tindakan)}

Setelah meyakinkan pelanggan untuk membeli produk, promosi kemudian harus mendorong mereka ke arah pembelian aktual. Tindakan atau action terjadi dengan adanya keinginan kuat dari pelanggan sehingga terjadi pengambilan keputusan dalam pembelian produk yang ditawarkan (Kotler dan Keller, 2009:178).

\section{Metode Penelitian}

Objek penelitian adalah pelanggan Gallery Dewdew Collection. Penelitian dilaksanakan mulai Maret hingga Agustus 2019 dengan jenis penelitian Kuantitatif deskriptif dan populasi terjangkau sebesar 35 responden serta sampel sebesar 35 responden yang merupakan seluruh pelanggan Gallery Dewdew Collection dengan menggunakan data cross sectional di bulan Juli 2019 yang dikumpulkan dari data 
hasil penjualan di Gallery Dewdew Collection dan wawancara. Metode penghitungan dilakukan dengan statistik sederhana dan analisis tabulasi dan menghitung rata-rata dari setiap dimensi Attention, Interest, Desire dan Action. Skala ukur yang digunakan adalah skala Guttman. Penelitian ini untuk menilai dan membuktikan hipotesa bahwa apakah promosi melalui media sosial yang dilakukan oleh Gallery Dewdew Collection efektif untuk membuat konsumen mau membeli di Gallery Dewdew Collection jika ditinjau melalui model AIDA (Attention, Interest, Desire, Action).

\section{Hasil Dan Pembahasan}

\section{Karakteristik Responden}

Karakterisktik responden dalam penelitian ini terbagi menjadi beberapa kategori yaitu usia, frekuensi kunjungan di media sosial (facebook, instagram) dan produk yang digunakan. Untuk usia responden terbagi menjadi 3 (tiga) rentang umur yaitu umur antara 17-19 tahun berjumlah 7 responden (20\%), umur 20-22 tahun berjumlah 17 responden (48,6\%), dan umur 23-25 tahun berjumlah 11 responden $(31,4 \%)$. Dalam hal frekuensi kunjungan konsumen di media sosial facebook yang digunakan oleh Gallery Dewdew Collection, terbagi menjadi 3 (tiga) kategori yaitu jumlah kunjungan antara 1-2 kali sebulan sebesar 7 responden (20\%), jumlah kunjungan antara 3-4 kali seminggu sebesar 16 responden (45,7\%), jumlah kunjungan setiap hari sebesar 12 responden $(34,3 \%)$.

Jumlah kunjungan untuk media sosial Instagram dalam frekuensi kunjungan antara 1-2 bulan sebesar 0 responden (0\%), 3-4 kali seminggu sebesar 3 responden $(8,6 \%)$, dan kunjungan setiap hari sebesar 32 responden $(91,4 \%)$. Sementara jumlah pengguna produk Gallery Dewdew Collection adalah terdiri dari Make Up Wisuda sebesar 8 responden (18\%), Class Modelling sebesar 24 responden $(55 \%)$, pengguna sewa gaun sebesar 8 responden (18\%) dan penguna paket make up pengantin sebesar 4 responden $(9 \%)$.

\section{Pengolahan Data Hasil Penelitian}

Uji Validitas \& Reabilitas 
Hasil uji validitas menyatakan bahwa dari 42 butir pertanyaan yang diajukan melalui kuesioner dengan menggunakan skala Guttman, tercatat jumlah error sebesar 7,29. Dengan menggunakan rumus koefisien Reprodusibilitas dan Skalabilitas, diperoleh hasil sebesar 0,995 dan 0,931 yang mana hasil ini dinyatakan valid. Sementara hasil uji reabilitas dengan menggunakan rumus Kuder Richardson 20 (KR 20) menunjukkan hasil sebesar 0,93 yang dinyatakan reliabel.

\section{Pembahasan/Interpretasi Hasil Penelitian}

Untuk mengukur efektivitas promosi di media sosial Gallery Dewdew Collection pada keputusan pembelian terdiri dari empat dimensi yaitu Attention, Interest, Desire, dan Action. Pengukuran empat dimensi tersebut diwakili oleh 42 pernyataan.

\section{Dimensi Attention (Perhatian)}

Pernyataan dimensi attention ditujukan untuk memunculkan perhatian pelanggan baik dalam bentuk dan media yang disampaikan dalam promosi di media sosial, membuat pelanggan mengerti pesan yang disampaikan dalam promosi, dan pelanggan mulai sadar mengenai keberadaan produk Gallery Dewdew Collection.

a. Hasil analisis tabulasi data sederhana dimensi attention

\section{Tabel 1}

\section{Analisis Tabulasi Data Sederhan Dimensi Attention}

\begin{tabular}{cccc}
\hline \multirow{2}{*}{$\begin{array}{c}\text { Atribut } \\
\text { pernyatan }\end{array}$} & \multicolumn{2}{c}{ Jumlah } & \multirow{2}{*}{ Total } \\
\cline { 2 - 3 } & Ya & Tidak & \\
\hline 1 & $74 \%$ & $26 \%$ & $100 \%$ \\
\hline 2 & $60 \%$ & $40 \%$ & $100 \%$ \\
\hline 3 & $97 \%$ & $3 \%$ & $100 \%$ \\
\hline 4 & $80 \%$ & $20 \%$ & $100 \%$ \\
\hline 5 & $63 \%$ & $37 \%$ & $100 \%$ \\
\hline 6 & $86 \%$ & $14 \%$ & $100 \%$ \\
\hline 7 & $91 \%$ & $9 \%$ & $100 \%$ \\
\hline 8 & $94 \%$ & $6 \%$ & $100 \%$ \\
\hline 9 & $83 \%$ & $17 \%$ & $100 \%$ \\
\hline
\end{tabular}




\begin{tabular}{llll}
\hline 10 & $80 \%$ & $20 \%$ & $100 \%$ \\
\hline 11 & $77 \%$ & $23 \%$ & $100 \%$ \\
\hline 12 & $94 \%$ & $6 \%$ & $100 \%$ \\
\hline
\end{tabular}

Sumber: Data primer diolah, Juli 2019

b. Total skor rataan dimensin attention

Tabel 1.1

Skor Rataan Dimensi Attention

\begin{tabular}{ccc}
\hline $\begin{array}{c}\text { Atribut } \\
\text { pernyataan }\end{array}$ & $\begin{array}{c}\text { Frekuensi X } \\
\text { Bobot }\end{array}$ & $\begin{array}{c}\text { Skor Rataan } \\
\text { per Atribut }\end{array}$ \\
\hline 1 & 26 & 2,17 \\
\hline 2 & 21 & 1,75 \\
\hline 3 & 34 & 2,83 \\
\hline 4 & 28 & 2,33 \\
\hline 5 & 22 & 1,83 \\
\hline 6 & 30 & 2,50 \\
\hline 7 & 32 & 2,67 \\
\hline 8 & 33 & 2,75 \\
\hline 9 & 29 & 2,42 \\
\hline 10 & 28 & 2,33 \\
\hline 11 & 27 & 2,25 \\
\hline 12 & 33 & 2,75 \\
\hline Total & $\mathbf{3 4 3}$ & $\mathbf{2 8 , 5 8}$ \\
\hline Sumber: Data primer diolah, Juli 2019 \\
\hline
\end{tabular}

Sumber: Data primer diolah, Juli 2019

Berdasarkan Tabel 1 dan Tabel 1.1, diketahui bahwa skor rataan dimensi attention sebesar 0,82. Skor tersebut selanjutnya dimasukkan dalam rentang skala AIDA Model. Hasil pengukuran promosi di media sosial berdasarkan dimensi attention dinyatakan efektif. Hal ini menginformasikan bahwa konsumen mengerti pesan yang disampaikan dan memperhatikan promosi di media sosial Gallery Dewdew Collection.

\section{Dimensi Interest (Ketertarikan)}

Pernyataan dimensi interest menginformasikan apa yang diberikan suatu 
promosi untuk meningkatkan kualitas suatu produk. Fitur dan manfaat produk yang dipromosikan melalui media sosial harus dapat membuat pelanggan tertarik. Bagi Gallery Dewdew Collection, dimensi Interset berarti harus menimbulkan perasaan ingin tahu, ingin mengamati, dan ingin mendengar serta melihat lebih seksama

a. Hasil analisis tabulasi data sederhana dimensi interest

Tabel 2

Analisis Tabulasi Data Sederhana Dimensi Interest

\begin{tabular}{cccc}
\hline \multirow{2}{*}{$\begin{array}{c}\text { Atribut } \\
\text { pernyatan }\end{array}$} & \multicolumn{2}{c}{ Jumlah } & Total (\%) \\
\cline { 2 - 3 } & Ya & Tidak & \\
\hline 1 & $100 \%$ & $0 \%$ & $100 \%$ \\
\hline 2 & $89 \%$ & $11 \%$ & $100 \%$ \\
\hline 3 & $94 \%$ & $6 \%$ & $100 \%$ \\
\hline 4 & $94 \%$ & $6 \%$ & $100 \%$ \\
\hline 5 & $100 \%$ & $0 \%$ & $100 \%$ \\
\hline 6 & $100 \%$ & $0 \%$ & $100 \%$ \\
\hline 7 & $91 \%$ & $9 \%$ & $100 \%$ \\
\hline 8 & $94 \%$ & $6 \%$ & $100 \%$ \\
\hline 9 & $97 \%$ & $3 \%$ & $100 \%$ \\
\hline 10 & $97 \%$ & $3 \%$ & $100 \%$ \\
\hline 11 & $89 \%$ & $11 \%$ & $100 \%$ \\
\hline
\end{tabular}

Sumber: Data primer diolah, Juli 2019

b. Total skor rataan dimensi interest

Tabel 2.1

Skor Rataan Dimensi Interest

\begin{tabular}{cccc}
$\begin{array}{c}\text { Atribut } \\
\text { pernyataan }\end{array}$ & $\begin{array}{c}\text { Frekuensi X } \\
\text { Bobot }\end{array}$ & $\begin{array}{c}\text { Skor Rataan } \\
\text { per Atribut }\end{array}$ & Total \\
\hline 1 & 35 & 3,18 & \\
\hline 2 & 31 & 2,82 & 0,95 \\
\hline 3 & 33 & 3,00 & \\
\hline 4 & 33 & 3,00 & \\
\cline { 1 - 3 } & 35 & 3,18 &
\end{tabular}




\begin{tabular}{ccc}
\hline 6 & 35 & 3,18 \\
\hline 7 & 32 & 2,91 \\
\hline 8 & 33 & 3,00 \\
\hline 9 & 34 & 3,09 \\
\hline 10 & 34 & 3,09 \\
\hline 11 & 31 & 2,82 \\
\hline Total & $\mathbf{3 6 6}$ & $\mathbf{3 3 , 2 7}$ \\
\hline \multicolumn{2}{r}{ Sumber: Data primer diolah, Juli 2019}
\end{tabular}

Berdasarkan Tabel 2 dan Tabel 2.1, diperoleh skor rataan dimensi interest sebesar 0,95. Skor tersebut selanjutnya dimasukan dalam rentang skala AIDA Model. Hasil pengukuran efektivitas promosi di media sosial tersebut masuk dalam rentang skala efektif dan menginformasikan bahwa melalui promosi di media sosial dapat meningkatkan daya tarik pelanggan Gallery Dewdew Collection dibandingkan media lainnya.

\section{Dimensi Desire (Keinginan)}

Pernyataan dimensi desire ditujukan untuk menciptakan kebutuhan calon konsumen, menggerakkan keinginan konsumen untuk memiliki dan menikmati produk. Bagi Gallery Dewdew Collection, dimensi Desire ditujukan untuk menggambarkan bagaimana konsumen melihat hubungan antara suatu iklan atau promosi dengan pribadi mereka serta menimbulkan keinginan konsumen untuk memiliki dan menikmati produk.

a. Hasil analisis tabulasi data sederhana dimensi desire

Tabel 3

\section{Analisis Tabulasi Data Sederhana Dimensi Desire}

\begin{tabular}{cccc}
\hline \multirow{2}{*}{$\begin{array}{c}\text { Atribut } \\
\text { pernyataan }\end{array}$} & \multicolumn{2}{c}{ Jumlah } & \multirow{2}{*}{ Total (\%) } \\
\cline { 2 - 3 } & Ya & Tidak & \\
\hline 1 & $80 \%$ & $20 \%$ & $100 \%$ \\
\hline 2 & $83 \%$ & $17 \%$ & $100 \%$ \\
\hline 3 & $89 \%$ & $11 \%$ & $100 \%$ \\
\hline 4 & $91 \%$ & $9 \%$ & $100 \%$ \\
\hline
\end{tabular}




\begin{tabular}{cccc}
\hline 5 & $83 \%$ & $17 \%$ & $100 \%$ \\
\hline 6 & $94 \%$ & $6 \%$ & $100 \%$ \\
\hline 7 & $91 \%$ & $9 \%$ & $100 \%$ \\
\hline 8 & $94 \%$ & $6 \%$ & $100 \%$ \\
\hline
\end{tabular}

Sumber: Data primer diolah, Juli 2019

b. Total skor rataan dimensi desire

Tabel 3.1

Skor Rataan Dimensi Desire

\begin{tabular}{cccc}
$\begin{array}{c}\text { Atribut } \\
\text { pernyataan }\end{array}$ & $\begin{array}{c}\text { Frekuensi X } \\
\text { Bobot }\end{array}$ & $\begin{array}{c}\text { Skor Rataan } \\
\text { per Atribut }\end{array}$ & Total \\
\hline 1 & 28 & 2,55 & \\
\hline 2 & 29 & 2,64 & 0,64 \\
\hline 3 & 31 & 2,82 & \\
\hline 4 & 32 & 2,91 & \\
\hline 6 & 29 & 2,64 & \\
\hline 7 & 33 & 3,00 & \\
\hline 8 & 32 & 2,91 \\
\hline Total & $\mathbf{2 4 7}$ & $\mathbf{2 2 , 4 5}$ \\
\hline
\end{tabular}

Berdasarkan Tabel 3 dan Tabel 3.1, diketahui bahwa skor rataan dimensi desire sebesar 0,64. Hasil pengukuran efektivitas promosi tersebut masuk dalam rentang skala efektif. Hal ini dapat diartikan bahwa setelah melihat promosi di media sosial Gallery Dewdew Collection meningkatkan keinginan pelanggan untuk memiliki dan menikmati produk Gallery Dewdew Collection.

\section{Dimensi Action (Tindakan)}

Tindakan atau action terjadi dengan adanya keinginan kuat dari pelanggan sehingga terjadi pengambilan keputusan dalam pembelian produk yang ditawarkan. a. Hasil analisis tabulasi data sederhana dimensi action 
Tabel 4

Analisis Tabulasi Data Dimensi Action

\begin{tabular}{cccc}
\hline \multirow{2}{*}{$\begin{array}{c}\text { Atribut } \\
\text { pernyatan }\end{array}$} & \multicolumn{2}{c}{ Jumlah } & \multirow{2}{*}{ Total (\%) } \\
\cline { 2 - 3 } & Ya & Tidak & \\
\hline 1 & $80 \%$ & $20 \%$ & $100 \%$ \\
\hline 2 & $86 \%$ & $14 \%$ & $100 \%$ \\
\hline 3 & $86 \%$ & $14 \%$ & $100 \%$ \\
\hline 4 & $71 \%$ & $29 \%$ & $100 \%$ \\
\hline 5 & $74 \%$ & $26 \%$ & $100 \%$ \\
\hline 6 & $74 \%$ & $26 \%$ & $100 \%$ \\
\hline 7 & $91 \%$ & $9 \%$ & $100 \%$ \\
\hline 8 & $69 \%$ & $31 \%$ & $100 \%$ \\
\hline 9 & $97 \%$ & $3 \%$ & $100 \%$ \\
\hline 10 & $86 \%$ & $14 \%$ & $100 \%$ \\
\hline 11 & $60 \%$ & $40 \%$ & $100 \%$ \\
\hline & Sumber: Data primer diolah Juli, 2019 &
\end{tabular}

b. Total skor rataan dimensi action

Tabel 4.1

Analisis Tabulasi Data Dimensi Action

\begin{tabular}{|c|c|c|c|}
\hline $\begin{array}{c}\text { Atribut } \\
\text { pernyataan }\end{array}$ & $\begin{array}{c}\text { Frekuensi X } \\
\text { Bobot }\end{array}$ & $\begin{array}{c}\text { Skor Rataan } \\
\text { per Atribut }\end{array}$ & Total \\
\hline 1 & 28 & 2,55 & \multirow{10}{*}{0,79} \\
\hline 2 & 30 & 2,73 & \\
\hline 3 & 30 & 2,73 & \\
\hline 4 & 25 & 2,27 & \\
\hline 5 & 26 & 2,36 & \\
\hline 6 & 26 & 2,36 & \\
\hline 7 & 32 & 2,91 & \\
\hline 8 & 24 & 2,18 & \\
\hline 9 & 34 & 3,09 & \\
\hline 10 & 30 & 2,73 & \\
\hline
\end{tabular}




\begin{tabular}{ccc}
\hline 11 & 21 & 1,91 \\
\hline Total & $\mathbf{3 0 6}$ & $\mathbf{2 7 , 8 2}$ \\
\hline & \multicolumn{2}{c}{ Sumber: Data primer diolah Juli, 2019 }
\end{tabular}

Berdasarkan Tabel 4 dan Tabel 4.1, diketahui bahwa skor rataan dimensi action sebesar 0,79 . Skor tersebut selanjutnya dimasukkan dalam rentang skala AIDA Model. Hasil pengukuran promosi di media sosial berdasarkan dimensi action dinyatakan efektif. Ini menunjukkan bahwa promosi yang dilakukan Gallery Dewdew Collection melalui media sosial mempengaruhi keputusan pembelian pelanggan dan responden telah benar-benar menggunakan produk Gallery Dewdew Collection.

Langkah selanjutnya menghitung rumus AIDA Model secara keseluruhan, yaitu sebagai berikut:

$$
\begin{gathered}
A I D A=\frac{\text { Attention }+ \text { Interest }+ \text { Desire }+ \text { Action }}{4} \\
A I D A=\frac{0,82+0,95+0,64+0,79}{4}=0,8
\end{gathered}
$$

Secara keseluruhan nilai AIDA Model bernilai 0,8. Nilai tersebut dapat diartikan bahwa pengukuran efektivitas promosi di media sosial pada keputusan pembelian pelanggan Gallery Dewdew Collection berdasarkan AIDA Model berada dalam kategori promosi efektif. Hal ini mencerminkan bahwa promosi di media sosial efektif menarik pelanggan untuk menggunakan produk Gallery Dewdew Collection.

\section{Kesimpulan}

Kesimpulan yang diperoleh dari penelitian ini adalah bahwa penggunaan media sosial yang dilakukan oleh Gallery Dewdew Collection untuk promosi dalam rangka mempengaruhi keputusan konsumen untuk membeli adalah efektif yang dibuktikan dari hasil penghitungan melalui model AIDA sebesar 0,8. Jika ditinjau dari pengukuran setiap dimensi AIDA, menunjukkan bahwa setiap dimensi memiliki efektifitas pesan yang baik. Sehingga dapat diterjemahkan bahwa dari aspek dimensi Attention, Gallery Dewdew Collection mampu menarik perhatian 
konsumen dengan baik dan mampu membuat konsumen paham mengenai produkproduk yang ditawarkan. Kemampuan Gallery Dewdew Collection menciptakan daya tarik produk melalui media sosial dalam menciptakan minat konsumen pun terbukti efektif yang ditunjukkan angka sebesar 0,95. Namun di sisi lain, Gallery Dewdew Collection masih harus bekerja keras untuk lebih meningkatkan minat konsumen lebih tinggi untuk membeli karena hasil penghitungan menunjukkan sebesar 0,64. Walaupun masih dalam kategori efektif namun hal itu masih dinilai belum cukup dalam upaya meningkatkan minat konsumen secara keseluruhan. Dimensi action masuk dalam rentang skala efektif dengan nilai 0,79 , yang mana kondisi ini perlu ditingkatkan lagi dalam rangka mendorong kegiatan membeli konsumen di Gallery Dewdew Collection. 


\section{DAFTAR PUSTAKA}

Clow, K. E., \& Baack, D. (2017). Integrated Advertising, Promotion, and Marketing Communications (Eighth Edi). London: Pearson Education Limited.

Ferrell, O. C., \& Hartline, M. D. (2011). Marketing Strategy (Fifth). Manson: South-Western Cengage Learning.

Jamaludin, A. (2015). Pengaruh Promosi Online dan Persepsi Harga Tehadap Keputusan Pembelian (Survei pada Pelanggan Aryka Shop di Kota Malang), 21(1).

Kotler, P., \& Armstrong, G. (2018). Principles of Marketing (Seventeen). London: Pearson Education Limited.

Kotler, P., \& Keller, K. L. (2009). Marketing Management. London: Pearson Education Limited.

Kotler, P., \& Keller, K. L. (2016). Marketing Management. Global Edition (Vol. 15E). Global Edition (Vol. 15E). https://doi.org/10.1080/08911760903022556

Putra, H. A. (2014). Pengaruh Iklan Online Melalui Media Facebook Terhadap Keputusan Pembelian Pakaian Mahasiswa Fakultas Ekonomi dan Bisnis Universitas Trunojoyo Madura. Jurnal Studi Manajemen, 8.

Ranginwala, S., \& Towbin, A. J. (2017). The Power of Promotion: Using Social Media to Promote a Radiology Department. Academic Radiology, 24(4), 488496. https://doi.org/10.1016/j.acra.2016.11.011 